\title{
School Literacy Movement (SLM) as a Solution to Increase Reading Interest of Indonesian Students
}

Ambar Sulistiyarini, Faculty of Teacher Training and Education, Universitas Sebelas Maret, Indonesia, Email: ambarsulistiyarini@student.uns.ac.id ORCID: 0000-0001-6253-8947

Sukarno Faculty of Teacher Training and Education, Universitas Sebelas Maret, Indonesia, Email: sukarno57@gmail.com ORCID: 0000-0003-2076-262X

Triyanto, Civic Education Departement, Universitas Sebelas Maret, Indonesia, Email: try_uns@yahoo.com ORCID: 0000-0003-0083-1018

Abstract. Reading is a very important activity in exploring knowledge and increasing insight. To carry out reading activities requires a sense of interest or encouragement that arises from within each individual called interest. Low interest in reading can make a nation lag behind various kinds of information that continues to grow today. This study aims to find out the implementation of the School Literacy Movement (SLM) as a solution to increasing reading interest. This research was designed with qualitative research methods using a purposive sampling technique. The subjects of this research were 27 fifth-grade students engaged in school literacy movement activities. The data collection techniques included observation, interviews, and documentation. The results of the present study revealed that the SLM habituation stage was able to increase students' reading interest by reading activities for fifteen minutes before learning. The effective reading activity was silent reading.

Keywords: Literacy, School Literacy Movement, Reading Interest Received: 16.11.2020 Accepted: 21.12.2020 Published: 06.01.2021

\section{INTRODUCTION}

The life in the 21st century has challenges driving every country to have qualified human resources with various skills. One of the skills having to be mastered is literacy skill (Wiedarti et al., 2018). Literacy is regarded as an important component to embody a country that is able to compete globally (Nurkaeti et al., 2019). Faizah et al (2016) explain that literacy skills are related to the demands of reading skills that lead to the ability to understand information analytically, critically, and reflectively.

The Program for International Student Assessment (PISA) is one of the studies developed to assess knowledge and skills about reading literacy, mathematical abilities, and scientific abilities in 15-year-old students. The PISA assessment is expected to assess the quality of education at school age to meet the challenges of human resources in the $21^{\text {st }}$ century. One component of $21^{\text {st }}$-century skills assessed by PISA is reading literacy. PISA (2009) explains that reading literacy is an individual's ability to understand, use, contemplate and engage with written texts that aim to achieve goals, develop individual knowledge and potential in order to participate in society.

Indonesia is one of the countries participating in the PISA test assessment. Indonesia has been participating since 2000 until now. From the results of the PISA assessment over the past 20 years, Indonesia is still in the bottom position. The following are the results of the reading score acquisition of Indonesia in the PISA assessment from 2000 to 2018:

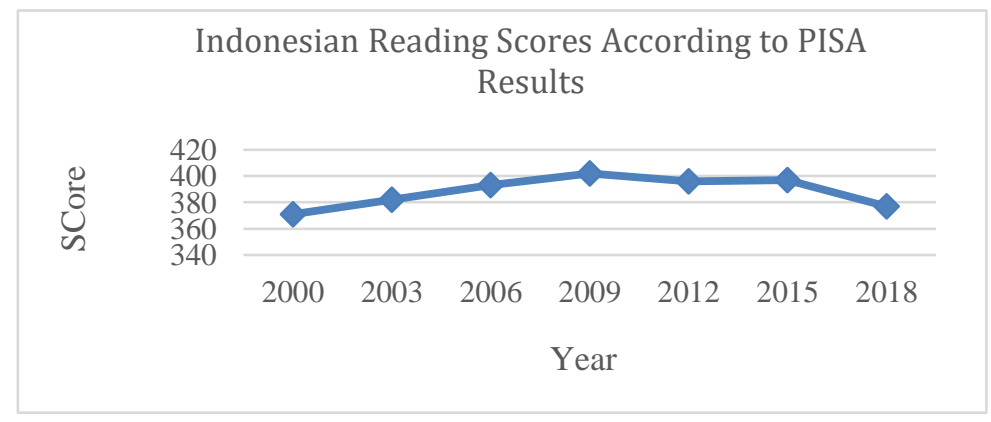

Diagram 1. Indonesian Reading Scores According to PISA Results (PISA, 2019) 
Based on the diagram above, Indonesian reading scores have not been able to show a significant increase, even decreased. In addition, the score are still below the international average score of 500 points. Compared with other developed countries, Indonesia is still significantly left behind in this $21^{\text {st }}$ century era. Moreover, PISA results in 2018 stated that Indonesia ranked $72^{\text {th }}$ of 78 participating countries.

If we look deeper, there are several factors that influence the low reading scores of Indonesia. One of them is students' reading interest and the availability of reading materials. Reading is like giving nutrition to our minds, by which we can get various kinds of new knowledge about science, technology, and other world advancements (Pasaribu, 2016). Reading interest is a strong drive for someone to read (Darmono, 2007), indicated by showing interest in various symbols(Sutarti, 2017). Reading interest is also defined as reading activities carried out by students outside the school (Mckool, 2000). Khairudin (2013) said that reading interest is determined by the number of books read in a month, favorite genre, and the type of English reading texts read. Thus, reading interest is one's internal drive to do reading activities outside of school activities.

This is as explained in the article entitled "Report of World's Most Literate Nations, Indonesian reading literacy emergency". The article explains that according to UNESCO data, the Indonesian reading index is around $\mathbf{0 . 0 0 1 \%}$ (Hamdani, 2019). Other facts are evidenced by the results of the Indonesia National Assessment Program (INAP) assessment, which show that the elementary school students have lack of reading skills by 46.83\% (GLN 2017 Guide, Ministry of Education and Culture). The foregoing indicates that Indonesian children still have low interest in reading due to the average reading index of the developed countries which ranges from $0.45 \%$ to $0.62 \%$ (Nurdiani et al., 2018; Sunardin, 2019).

The low reading interest proves that the educational process has not been able to develop the competence and interest in reading to students optimally. In fact, Indonesia has 1,095 study hours per year, while Japan has only 712 study hours per year (Endah et al., 2018). Such conditions should be used to improve the abilities of students, including reading interest. Gary and Timothy (1998) explain that a teacher should be able to provide a basis for finding learning activities. It aims to make students more interested in reading and help them to have a high reading interest.

If the student's lack of reading interest is not paid any attention, then Indonesia will be left behind with other developed countries, such as Japan, Singapore and Finland. The government has made various attempts to fix the problem. Through the issuance of Minister of Education and Culture Regulation No. $23 / 2015$ on the Character Building, one of the objectives is to strengthen the culture of student literacy by implementing the activity of reading non-schoolbooks for 15 minutes before the lesson. The activity was then realized in the "School Literacy Movement (SLM)" program.

SLM is an effort made to habituate, develop, and embed literacy comprehensively and sustainably (Burhan et al., 2020). Some activities and the completion of infrastructure and facilities are carried out as evidence of the SLM implementation in elementary schools. The activities which can be applied by teachers in civilizing literacy in elementary schools include observing, creating, informing, appreciating, posting, and exhibiting (Akbar, 2017). In the meantime, the facilities that support SLM activities include the availability of a class reading corner, the reading areas around the school environment, a rich text environment, and the development of reading interest (Faradina, 2017).

The SLM program launched by the government is indeed supposed to be supported by various parties. Based on the conditions in the field, many schools have started implementing the SLM program. The schools which are the core schools are used as pilot schools in the implementation of SLM for the surrounding schools. In addition, there is also a need for various readiness for the sustainability of SLM, namely the readiness of school capacity (availability of facilities, reading materials, facilities, and literacy infrastructure), readiness of school members, and the readiness of other support systems (public participation, institutional support, and relevant policy tools) (Wiedarti et al., 2018).

SLM is a program undertaken over a long period of time so that its implementation requires several stages. There are three stages of SLM implementation, namely habituation, development, and learning (Faizah et al., 2016, p. 5). The habituation activity is carried out with 15 minutes of reading (the teacher reads books, and students read along silently, adjusted to the context or target of the school). After the reading habit is formed, it will then be directed towards development and learning. Variations in activities can be in the form of a combination of the development of receptive and productive skills (Wandasari, 2017).

Habitation is the initial stage of SLM designed to foster school community's interest in texts and reading activities (Faizah et al., 2016, p. 5; Wiedarti et al., 2018, p. 29). To foster students' interest in reading at the habituation stage, SLM does not merely focus on the use of libraries, but it also tries to create a reading environment in every corner of the school. This will make students easier to create a pleasant reading atmosphere. SLM is done not only by students but also by entire school community. 
Teachers, school principals, and even parents, should give examples to students to do reading activities. With the cooperation of various parties and all the readiness of the school, this program will have more influence on students' reading interest.

The above explanations demonstrate the urgency of increasing Indonesian students' interest in reading and literacy. Thus, an in-depth study of SLM is considered necessary to be conducted as a solution to increase students' reading interest. In this study, the researchers focus on the habituation stage of SLM. Many prior studies have examined the efforts to increase students' interest in reading (Anjani et al., 2019; Hejase et al., 2019; Heru \& Samsi, 2017; Springer et al., 2017; Sutrisna et al., 2019; Walipah et al., 2020). However, they have not used SLM especially at the stage of habituation as an effort to increase students' reading interest. The application of SLM in this research is a separate strength for the success of the curriculum in Indonesia. As it is known that each level demands knowledge competencies that require various kinds of information. One of the information is obtained through reading activities. To obtain information is not only obtained by reading once but requires a process or repeatedly. Thus, students will absorb more of the subject matter because they are used to learning by cultivating reading as in the GLS habituation stage.

Furthermore, the habituation stage is the most important initial stage to increase students' reading interest. A habituation will last until the end of life (Purwadi et al., 2019). Through habituation, reading activities will become students' habits and will indirectly be embedded in students for a long period of time. The habituation stage, undertaken through a reading activity for 15 minutes before the lesson, shows that under such a condition students are still fresh and ready (Yulianto \& Maman, 2019). Furthermore, Triyanto and Krismayani (2019) said that habituation activities were able to add insight and knowledge through the materials contained in reading books. Reading habit will add students' vocabularies and train their abilities to retell and respond to reading. Other talents that can be seen due to SLM activities at the habituation stage include the students' ability to speak publicly such as storytelling and poetry reading. Therefore, this study aims to find out the implementation of the School Literacy Movement (SLM) as a solution to increasing reading interest by focusing on the habituation stage.

\section{METHODS}

\section{Research Design}

This study was designed based on a qualitative research method using a purposive sampling technique. Qualitative research is research conducted on natural objects, developing as it is, not manipulated by researchers and researchers do not affect the dynamics of these objects. In this study, the School Literacy Movement at the habituation stage included the focused activity at the habituation stage and students' reading interest.

\section{Participants}

Participants used in the study were 27 students (17 male and 10 female) in the fifth grade of Karangduwur 1 Elementary School. All students are actively involved in the activities of the School Literacy Movement. Out of 10 female students, there is 1 student with special needs. They are taught by 2 teachers, namely the class teacher and the companion teacher. This research was conducted from September to December 2019.

\section{Instruments}

The GLS activity in the habituation stage is carried out for 30 minutes with details of 15 minutes of reading and 15 to fill in literacy books as a follow-up form of reading activities. The aspects studied include the focus of the activity in the habituation stage the students' reading interest. 
Table 1. Aspect Indicators of Activity Focus and Students' Reading Interest

\begin{tabular}{|l|l|}
\hline Aspects & \multicolumn{1}{|c|}{ Indicator } \\
\hline The Focused Activity at the & $\begin{array}{l}\text { Books read are reading books, not textbooks } \\
\text { The books read are of interest to students. } \\
\text { The activities of reading books at the habituation } \\
\text { stage are not followed by tasks of memorizing stories, } \\
\text { writing synopsis, etc. } \\
\text { The activity of reading books at this stage of } \\
\text { habituation can be followed by informal discussions } \\
\text { about the books } \\
\text { or fun activities related to the books read when } \\
\text { possible. } \\
\text { The activity of reading books at this stage of } \\
\text { habituation takes place in a relaxed and pleasant } \\
\text { atmosphere }\end{array}$ \\
$\begin{array}{l}\text { Many books are read in one month } \\
\text { The type of reading that is often read } \\
\text { Factors affecting reading interest }\end{array}$ \\
\hline Reading Interest
\end{tabular}

\section{Data Collecting}

The techniques of collecting data deployed in this study were observation, interviews and documentation. Observations were made when the school literacy movement activity was implemented. Interviews were conducted with students, the principal, and the class- $V$ teacher. In the meantime, the documentation used was in the form of archives or documents compiled during the SLM activity, namely SAP (School Activity Plan), students' literacy books, and literacy reading materials.

\section{Data Analysis}

The technique of data analysis was done by data reduction, data presentation, and data verification. To analyze the habituation stage of School Literacy Movement, there were several predetermined criteria. First, the analysis of the focused activity at the habituation stage was realized in the form of indicators of the provisions of silent reading activity. Second, the analysis of students' reading interest was seen based on the reading skill generated during the SLM activity through students' literacy books.

\section{RESULTS}

\section{The Focused Activity at the Habituation Stage}

Researchers used observation and interviews to find out the results of the focus of activities in the habituation stage. Based on the results of the interview given to the class teacher for the questions, "How is the implementation of literacy activities in this school?". The teacher answered, "Literacy is various, it can extend to story-telling, watching educational videos, reading, and visiting library or community leaders. The activities most often undertaken in general are reading activities, and one of which is silent reading." Grounded in the foregoing statements, it could be seen that the literacy activity applied in the field was a silent reading activity.

Based on observations in the field, the researcher presents aspects of the activity of the reading silently at the stage of habituation:

Tabel 2. Observation Results Reading Activities Silently at The Habituation Stage

\begin{tabular}{|l|l|}
\hline Principles of Reading Activities & Remark \\
\hline $\begin{array}{l}\text { Books read are reading books, not } \\
\text { textbooks }\end{array}$ & $\begin{array}{l}\text { The reading books available in the class reading corner are } \\
\text { educational comic books, magazines, picture story books, } \\
\text { picture books full of text, encyclopedias, and Islamic story } \\
\text { books. }\end{array}$ \\
\hline $\begin{array}{l}\text { The books read are of interest to } \\
\text { students. }\end{array}$ & $\begin{array}{l}\text { Books that are of interest to students are educational comic } \\
\text { books, picture story books, and magazines. }\end{array}$ \\
\hline $\begin{array}{l}\text { The activities of reading books at the } \\
\text { habituation stage are not followed by } \\
\text { tasks of memorizing stories, writing }\end{array}$ & $\begin{array}{l}\text { The teacher does not give assignments to memorize, write } \\
\text { synopsis, and others, but to monitor the students' literacy, } \\
\text { the teacher provides literacy books that must be filled out }\end{array}$ \\
\hline
\end{tabular}


synopsis, etc.

The activity of reading books at this stage of habituation can be followed by informal discussions about the books or fun activities related to the books read when possible.

The activity of reading books at this stage of habituation takes place in a relaxed and pleasant atmosphere after reading.

The teacher gives time to read for 15 minutes before the lesson and 15 minutes to fill in the literacy book, so the teacher does not always have informal discussions with students. However, at the end of each month, the teacher will conduct an evaluation of the literacy activities carried out.

The teacher gives freedom to students when doing literacy activities. The teacher does not hesitate to greet and approach students during literacy activities.

Based on Table 2, it can be seen that first, the use of reading material books in GLS activities is in the form of non-lesson books that are already available in the reading corners of the class. Students can freely choose the books they like. The second stage shows that of the various kinds of books that have been provided, most of the students have a high interest in fiction books in the form of educational comics, picture storybooks, and magazine books. In the third stage, the teacher does not give assignments after reading activities. Students only take notes to read what they have read in student literacy books. In the fourth stage, discussion activities are not always provided by the teacher. This is because it is constrained by the time that occurs due to GLS activities after material. in the fifth stage, the teacher gives freedom to students during literacy activities. This aims to make students feel comfortable and enjoy ongoing activities.

\section{Reading Interest}

The follow-up form of reading activities at the habituation stage is that students write what they have read in student literacy books. With these activities, researchers were able to find out how many books students read in five months. The following is an example of a student literacy activity book used during research.

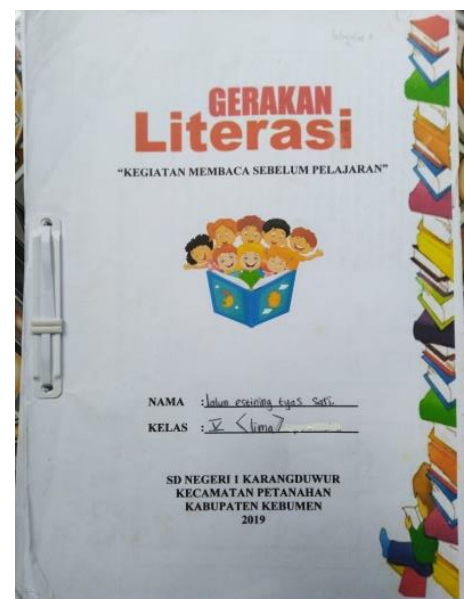

Picture 1. Student literacy books

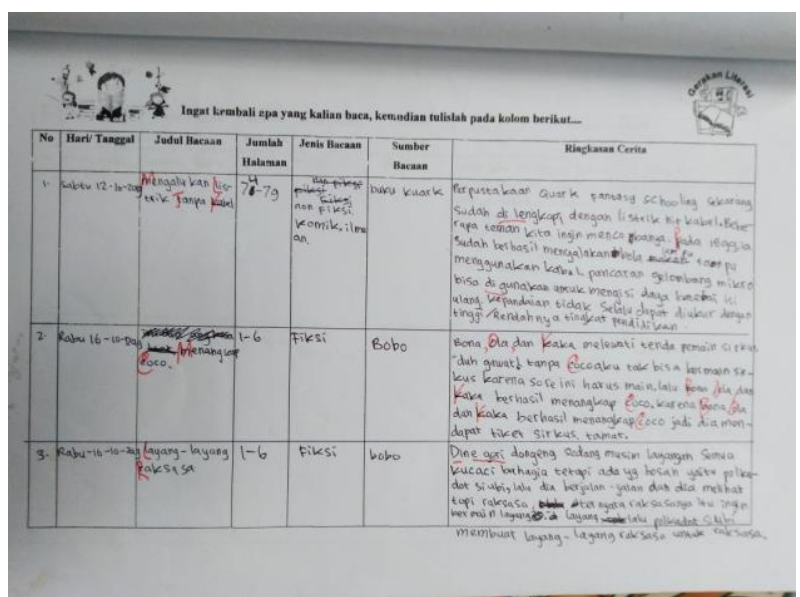

Picture 2. Student reading results

The researcher conducted an analysis of the literacy books owned by each student to determine the level of students' reading interest. The researcher compared the number of books students read at the beginning and the end of the month of the study. The following diagram presents the results of the analysis of students' reading interest in literacy activities in fifth-grade students of Karangduwur 1 Elementary School: 


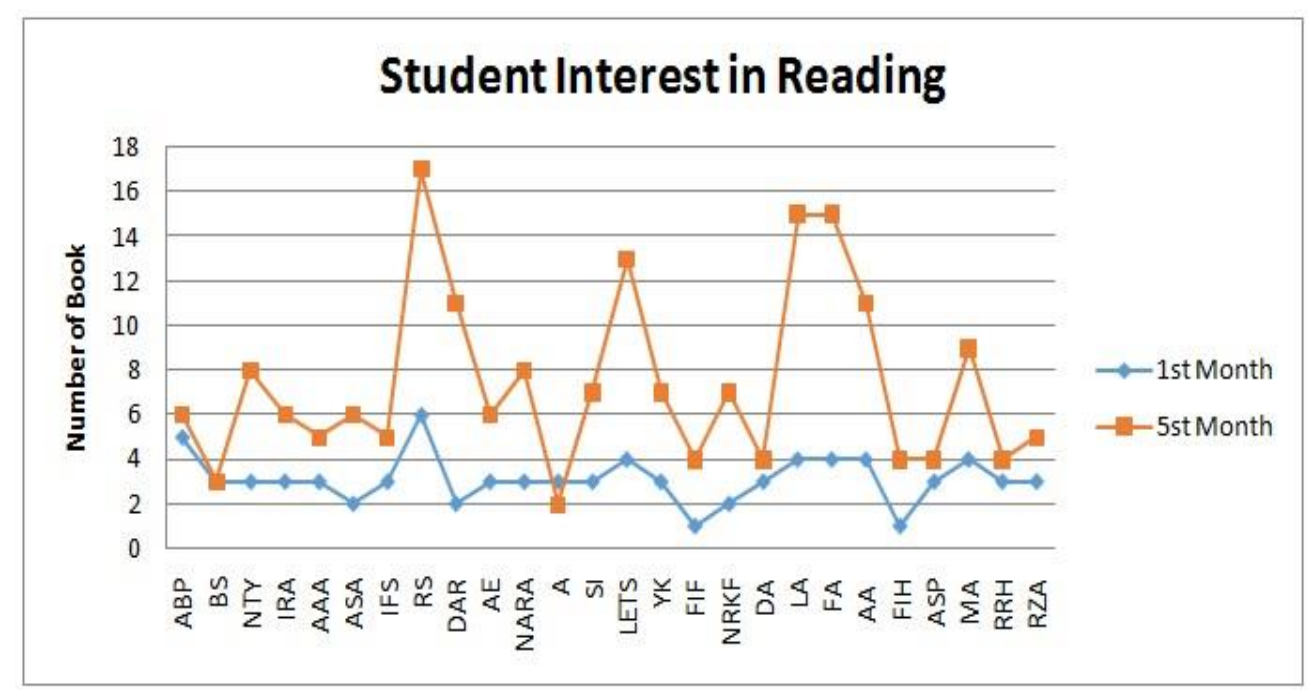

Diagram 2. Student Reading Interest

The diagram above depicts the comparison of students' reading interest in the first month and in the fifth month based on the number of books read. From the analysis of 27 students, 6 students have high reading interest, 10 students have moderate reading interest, and 11 students have low reading interest. Students have high reading interest if they can read more than 10 books in five month, they have moderate reading interest if reading more than 6-10 books in five month, and their reading interest is low if they can only read 1-5 books in five month.

\section{DISCUSSION AND CONCLUSIONS}

Based on the results of the observations in Table 2 it could be seen that first, the existence of a class reading corner is a kind of effort made to create a literal environment that is able to develop students' reading interest (Nurkaeti et al., 2019; Wandasari et al., 2019). The aforesaid non-lesson reading books are those containing the materials as regards moral values such as local, national, and global wisdom delivered in accordance with the stages of students' development (Silvia \& Djuanda, 2017; Teguh, 2017). According to the Language Development and Coaching Agency (Bahasa, 2016), there is a criterion of the books used for literacy, namely non-learning books that are positively charged. The books are in the form of magazines, story books, comics, novels, and so on. Wiedarti et al $(2018$, p. 35) further stated that the types of reading materials that can be used in SLM activities are picture books, rich text picture books, and beginner novel books that can be presented in print, digital, or visual art. This is in line with the study findings conducted by Burhan et al (2020) revealing that the selected books used for literacy are fiction and nonfiction books that can be in the form of informational books, short story books, novels, tales, and stories that contain the cultivation of character and moral value. Analysis of the use of non-reading materials was done resting upon the reality in the field.

Second, the books read were those relevant to students' interest. This point was in light of that the provision of reading materials at the habituation stage was already adjusted to students' characteristics. The foregoing statement is supported by Batubara and Ariani (2018) who said that the selection of story books used in literacy activities is according to students' characteristics and desires. In addition to adjusting reading materials, the teacher also gave freedom to students to choose their preferred reading materials. As stated by Mercedes et al. (2020), students must be given the opportunity to independently read the books they are interested in so that this way will build their enthusiasm, achievement, and motivation to read. Such freedom to select reading materials rests upon an expectation that students can enjoy reading their materials so they can understand what they read, and their interest in reading will be greater (Khotimah et al., 2018).

Third, the activity of reading books at the habituation stage was not followed by the tasks of memorizing stories, writing synopsis, and others. The habituation stage was a stage of creating students' interest so that in its implementation the reading activity was carried out without burdening students. Students were first made to love reading. To monitor the reading activity having been carried out, the teacher provided students' literacy books containing the data report of the reading activity done by students. Such an activity is a form of follow-up to the SLM activity, namely providing activities that must be carried out after reading such as questioning, answering, and recording of the books already read by both students and teachers (Khotimah et al., 2018). 
The students' literacy books would be monitored by the teacher once a month. Students who were able to read the most reading materials would be given a reward by the teacher. This reward was applied as a motivation for students to be more active in reading. Teguh (2017) stated that reading award is an activity designed to appreciate students who read the most at the scale of school, district / city, or provincial level. It aims to stimulate students to continue reading. Analysis related to the assignment given during the habituation stage showed that the school never charged students with assignments as a follow up to the reading activity. However, students were required to write what they already read in students' literacy books as a form of recording that they had followed the silent reading activity.

Fourth, there was an informal discussion about the books read. The discussion activity was carried out with the aim of reviewing what students already read. As explained by Rahayu et al (2017), after students finish reading silently, the teacher can ask about the characters, plot, or moral messages from a story to embed senses. In addition, discussion is carried out when students encounter difficulties in understanding what they read. Based on observations in the field, the SLM activity at the habituation stage was carried out for 30 minutes with the details of fifteen minutes used for silent reading and fifteen minutes for writing reports in students' literacy books. Based on the results of interviews with the grade five teacher, he stated that the discussion activity was constrained by time because after the SLM activity was undertaken students began their formal teaching and learning activities. However, if the time was still adequately available, he used to ask questions related to what students read briefly. Furthermore, when students experienced distress, the teacher also did not hesitate to help solve their problems. Appertaining to the analysis related to informal discussion at the habituation stage, the teacher had not yet maximally implemented informal discussion because it was constrained by time. Such a discussion was conducted only if plausible.

Fifth, the silent reading activity was carried out in a relaxed and pleasant atmosphere. One factor that supports literacy at the habituation stage is the creation of an adequate physical environment or facilities. Maharsi et al. (2019) stated that reading activities can be fun if all facilities and infrastructure fully support the activities. This statement is supported by Wibowo's (2019) opinion stating that the implementation of SLM is done through the programs and the provision of school facilities aimed at making students literate.

A safe and pleasant atmosphere was not far from the completeness of facilities and infrastructure to support literacy activities in the classroom. The aforementioned infrastructure was the availability of the class reading corner or class library. The library and class reading corner must be equipped with books that are varied and arranged in an attractive way (Rahayu et al., 2017). The availability of these facilities made it easier for students to pick and choose reading materials without having to get out of the room. The other completeness was the availability of posters supporting the SLM activity. Posters were a form of invitation to students. Posters which were posted should contain interesting things that could arouse students' interest in reading. Based on observations in the classroom, there was a class reading corner with a variety of reading materials and also posters attached to the classroom wall. Analysis related to creating a comfortable and pleasant atmosphere showed that the condition in the field was appropriate for this entity.

Interest is a desire that is owned by individuals. Each individual has a different interest in something. Nordin dan Eng (2017) said that interest is a strong motivational variable in someone's life that involves someone's experience in an object, event, activity, or idea that he/she is familiar with. Reading interest is a strong sense of desire for someone to carry out reading activities on their own consciousness so that information can be obtained (Faradina, 2017). One of the activities to increase students' interest in reading is to apply the school literacy movement. The SLM activity at the habituation stage is reading for 15 minutes before the lesson which aims to foster interest in texts and reading activities amid the school community (Wiedarti et al., 2018, p. 29). If the habit of reading is done continuously, it will form the character of interest in reading (Anjani et al., 2019). In addition, the existence of a class library as a reading corner that provides various types of reading is a form of school's effort to create a literal environment to develop students' reading interest (Nurkaeti et al., 2019). Students are given the freedom to choose and read books they enjoy.

The diagram above depicts the comparison of students' reading interest in the first month and in the fifth month based on the number of books read. From the analysis of 27 students, 6 students have high reading interest, 10 students have moderate reading interest, and 11 students have low reading interest. Students have high reading interest if they can read more than 10 books in five month, they have moderate reading interest if reading more than 6-10 books in five month, and their reading interest is low if they can only read 1-5 books in five month. This is aligned with Dag's (2017) opinion that the very good readers are able to read twenty one or more books per year; moderate readers are able to read six to twenty books a year; low readers read one to five books a year; and people who do not read books are 
called non-reader. In the results of the study, it is stated that students who have a high interest in reading are able to read more than 10 books in five months. If this is done consistently, then in one year students are able to read above 20 books. Dag (2017) stated that good readers are able to read more than 20 books every year.

Resting on the results of graph analysis, there is a difference in the line between the first month and the fifth month. That is because there is an increase in students' reading interest. Grounded in field observations, in the first month of SLM implementation, students still made adjustments to the SLM program because not all students had the habit of reading. Over time, students got used to doing literacy activities held every Wednesday and Saturday. After five months, several students who had a high interest in reading could be seen. Students' interest in reading does not necessarily exist. For children, the elementary school stage is a critical period for forming reading habits because they need a good reading base to receive, master, and combine knowledge (Zhao et al., 2018). A reading activity is carried out in a fun way and in a good environment. This will arouse students' interest in reading (Ista et al., 2019). When students are interested in a topic or text, it will affect their mood so that they will get involved in reading (Rumainah, 2018).

The analysis results of students' literacy books showed that students were interested in picture books and educational comics. Most female students preferred to read picture books. After being asked why they liked picture books, they said that they were interested in the pictures so they wanted to read the story. In the meantime, male students were more interested in comic reading materials. The packaging of comic reading materials had a special attraction for male students. The results of this study are supported by this study conducted by Kerneža and Khošir (Kerneža \& Košir, 2016) which states that the use of comics as a literary-didactic method have a positive effect on student literacy and motivate students to read. Also, the research results of Istiq'faroh et al., (2020) stated that the use of illustrated Indonesian folklore books significantly improved reading comprehension and motivation of students in the experimental group compared to control group students. Thus, the use of educational comic books and illustrated folklore books was able to increase student motivation in reading. The interest, level of the book, topic and content of the book, page number, clasification of the information in the book, pace of the book, factors related to cover page, and contribution of the book to the education of students are significant factors in choosing the books they will read (Ateş et al., 2012)

On the other hand, the analysis results of students' reading interest showed that students who were fond of reading were mostly female students. This is similar to the results of Hejase's et al (Hejase et al., 2019) study exhibiting that of 389 Czech students female students expressed their pleasure in reading rather than boys. Based on the results of interviews conducted with students who had a high interest in the question "what causes you to enjoy reading?", They said that there was motivation and desire embedded in them. They added that by reading they would have their knowledge increase. This is supported by Maharsi's et al. (Ista et al., 2019) statement that there are many benefits obtained from reading, including being able to obtain information, broaden insight, and feel pleasure in reading. The provision of varied reading materials available in the class reading corner was also recognized as capable of influencing students' interest in reading. Students who were fond of reading said that they enjoyed the SLM activity because in the class reading corner there were many books provided. The students had a great curiosity every time there was a new reading material. In addition, the reading award was also one of the factors driving the students' high interest in reading. They were motivated by the reading award given by the teacher every month.

Anchored in the presentation of findings in the field, it can be seen that the school literacy movement at the habituation stage can increase students' reading interest. This is supported by the study results stating that literacy programs are able to produce students' positive attitudes towards reading, students' higher involvement, and the increased reading achievement (Anjani et al., 2019; Heru \& Samsi, 2017; Steve et al., 2016; Sutrisna et al., 2019; Tichenor et al., 2020). Some factors that can increase students' reading interest are high motivation and curiosity for each new book, awareness of the benefits of reading which are obtained, the provision of varied reading materials, and the provision of reading awards given by teachers. Also, providing a learning environment is one of the important things that can affect students' reading motivation(Aydemir \& Öztürk, 2013). As Anjani's et al (2019) opinion, a student who has a high reading interest needs a number of things including a supportive environment, interesting reading materials, and guidance on reading which is appropriate to the student's age level. This is reinforced by Faradina's (2017) opinion that there are internal and external factors that affect interest in reading. Internal factors that influence students' interest in reading according to this study are the high motivation and curiosity of each new book and the awareness of reading benefits which are obtained. In the meantime, the external factors that influence students' interest in reading are in the form of providing varied reading materials and the existence of reading awards given by teachers. 
In addition, the involvement of the school environment and teachers is considered able to increase Indonesian students' reading interest (Komalasari et al., 2018). Dağ (2017) stated that to maintain students' interest and motivation towards reading, teachers can do this by conducting class discussions concerning books or texts, arranging book exhibitions at school, promoting books regularly, and ensuring students to exchange books. Subsequently, Rohman (2017) added that a child who has a high interest in reading needs a number of things including a supportive environment, interesting reading material and guidance on reading that is appropriate to the child's age level. Hence, to increase students' interest in reading through the school literacy movement program at the habituation stage, it must involve all aspects of the school environment such as the principal, teachers, committees, and students to participate in it.

Based on the results of the discussion above, it can be concluded that SLM is an effort made to habituate, develop, and teach literacy comprehensively and sustainably. The habituation stage in SLM is one of the stages aimed at increasing students' interest in reading. The main activity at the habituation stage is a reading activity for fifteen minutes before the lesson by reading aloud and reading silently. The provisions of silent reading activity at the habituation stage include: (1) the books read are not textbooks, (2) the books read are those based upon students' interest, (3) the reading activity at the habituation stage is not followed by tasks for memorizing stories, writing synopsis, and etc. (4) The activity of reading books at the stage of habituation can be followed by an informal discussion about the books being read or a fun activity related to the books read if time is plausible; (5) The reading book activity at the stage of habituation takes place in a relaxed and pleasant atmosphere. The results of the study showed that there are 6 students who have high reading interest; 10 students have moderate reading interest, and 11 students have low reading interest. There are several factors that affect students' interest in reading, namely internal and external factors. Internal factors are indicated by high motivation and curiosity for each new reading material, while external factors include the provisions of varied reading materials and reading awards given by teachers.

\section{REFERENCES}

Akbar, A. (2017). Membudayakan Literasi dengan Program 6M di Sekolah Dasar. 3(1), 42-52.

Anjani, S., Dantes, N., Artawan, G., Studi, P., Dasar, P., \& Pascasarjana, P. (2019). Pengaruh Implementasi Gerakan Literasi Sekolah Terhadap Minat Baca dan Kemampuan Membaca Pemahaman Siswa Kelas V SD Gugus II Kuta Utara. Jurnal Pendidikan Dasar Indonesia, 3(2), 74-83.

Ateş, S., Çetinkaya, Ç., \& Yildirim, K. (2012). How to Choose a Readable Book ?. İlköğretim Online, 11(2), 319-331. http://ilkogretim-online.org.tr

Aydemir, Z. I., \& Öztürk, E. (2013). Reading motivation scale for texts: A validity and reliability study. Elementary Education Online, 12(1), 66-76.

Bahasa, B. P. dan P. (2016). Pedoman Pelaksanaan Gerakan Nasional Literasi Bangsa. Kementrian Pendidikan dan Kebudayaan.

Batubara, H. H., \& Ariani, D. N. (2018). Implementasi Program Gerakan Literasi Sekolah di Sekolah Dasar Negeri Gugus Sungai MIAI Banjarmasin. JPSD, 4(1), 15-29.

Burhan, N. S., Nurchasanah, \& Basuki, I. A. (2020). Implementasi Tahap Pembiasaan Gerakan Literasi Sekolah. Jurnal Pendidikan: Teori, Penelitian, Dan Pengembangan, 5(3), 367-373.

Dağ, N. (2017). The Reading Profile of Turkish Primary School Students. International Journal of Instruction, 10(4), 293-306.

Darmono. (2007). Perpustakaan Sekolah: Pendekatan Aspek Manajemen dan Tata Kerja. Grasindo.

Endah, S., Thahar, H. E., \& Asri, Y. (2018). The contribution of reading interest on literature and reading comprehension toward students ' ability in writing fantasy story. International Conferences on Education, Social Sciences and Technology, 955-960.

Faizah, D. U., Sufyandi, S., Anggriani, L., Waluyo, Dewayani, S., Muldian, W., \& Roosaria, D. R. (2016). Panduan Gerakan Literasi Sekolah di Sekolah Dasar. Direktorat Pembinaan Sekolah Dasar.

Faradina, N. (2017). Pengaruh Program Gerakan Literasi Sekolah Terhadap MInat Baca Siswa di SD Islam Terpadu Muhammadiyah An-Najah Jatinom Klaten. Jurnal Hanata Widya, 6(8), 60-69.

Gary, P. M., \& Timothy, G. M. (1998). Increasing students' achievement and interest in reading. The Berkeley Electronic Press (bepress).

Hamdani. (2019, January 28). Laporan World's Most Literate Nations, Indonesia darurat literasi membaca. Kompasiana.Com, $1-3$. https://www.kompasiana.com/cangkoiburong/5c4ec840c112fe193a7a94a5/laporan-mostliterred-nation-in-the-world-indonesia-darurat-literasi-membaca?page=all

Hejase, A. J., Hejase, H. J., Younis, J., \& Abbas, O. (2019). Reading Interests and Habits in Lebanon: 
Explorative Analysis Reading Interests and Habits in Lebanon : Explorative Analysis. Saudi Journal of Humanities and Social Sciences, 4(3), 149-166. https://doi.org/10.21276/sjhss.2019.4.3.2

Heru, S., \& Samsi, H. (2017). Implementasi Gerakan Literasi Sekolah dalam Menumbuhkan Minat Membaca Siswa di SMP Negeri 2 Pleret Kabupaten Bantul. Jurnal Penelitian Dan Evaluasi Pendidikan, 5(2), 68-82.

Ista, M., Izam, G. M., \& Salma, M. (2019). High School Students, Reading Habt and Perception on Reading for Pleasure. International Journal of Indonesian Education and Teaching, 3(1), 80-89.

Istiq'faroh, N., Suhardi, S., Mustadi, A., \& Ahdhianto, E. (2020). The effect of indonesian folktales on fourthgrade students' reading comprehension and motivation. Elementary Education Online, 19(4), 21492160. https://doi.org/10.17051/ilkonline.2020.763772

Kerneža, M., \& Košir, K. (2016). Comics as a literary-didactic method and their use for reducing gender differences in reading literacy at the primary level of education. Center for Educational Policy Studies Journal, 6(2), 125-149.

Khairuddin, Z. (2013). A Study of Students 'Reading Interests in a Second Language. 6(11), 160-170. https://doi.org/10.5539/ies.v6n11p160

Khotimah, K., Akbar, S., \& Sa, C. (2018). Pelaksanaan Gerakan Literasi Sekolah. Jurnal Pendidikan: Teori, Penelitian, Dan Pengembangan, 3(11), 1488-1498.

Komalasari, M. D., Wibowo, A., \& Anggraeni, D. (2018). Pendampingan Gerakan Literasi Sekolah Dalam Pembelajaran Di Sekolah Dasar. Jurnal Abdi Masyarakat, 2(1), 1-8. https://doi.org/10.30737/jaim.v2i1.236

Mckool, S. S. (2000). FACTORS THAT INFLUENCE THE DECISION TO READ : AN INVESTIGATION OF FIFTH GRADE STUDENTS ' OUT-OF-SCHOOL READING HABITS. Reading Improvement, 44(3), 111132.

Nurdiani, S., Syahrul, R., \& Abdurahman. (2018). The Relationship of Vocabulary and Reading Comprehension in the Writing Skills Descriptive Text Reviewed Gender. International Conferences on Education, Social Sciences and Technology, 848-853.

Nurkaeti, N., Aryanto, S., \& Gumala, Y. (2019). Read Aluod: An Literacy Activity in Elementary School. Jurnal of Elementary Education, 3(2), 55-61.

Pasaribu, E. (2016). The Correlation of Students ' English Reading Interest at Library on Students ' Vocabulary Achievement at the Teacher Training Faculty Of Nommensen University Pematangsiantar. 21(2), 39-44. https://doi.org/10.9790/0837-21213944

PISA. (2009). PISA 2009 Assessment Framework Key competencies in reading, mathematics and science. In PISA 2009 (pp. 9-249). OECD.

PISA. (2019). (https://www.oecd.org/pisa/publications/).

Purwadi, P., Hendrik, M., \& Arafatun, S. K. (2019). Gerakan Literasi Sekolah (gls) Tahap Pembiasaan: Perbedaan Implementasi antara SD Negeri 3 Pangkalpinang dengan SD STKIP Muhammadiyah Bangka Belitung. Seminar Nasional Pendidikan Fakultas Ilmu Pendidikan, 280-296.

Rahayu, R. A., Degeng, I. N. S., \& Sa'dun, A. (2017). Gerakan Literasi Sekolah sebagai Upaya Penumbuhan Karakter Siswa Sekolah Dasar. Transformasi Pendidikan Abad 21, 1060-1067.

Rohman, S. (2017). Membangun Budaya Membaca Pada Anak Melalui Program Gerakan Literasi Sekolah. Jurnal Pendidikan Dan Pembelajaran Dasar, 4(1), 151-174.

Rumainah. (2018). Undergraduate Students ' Reading Interest and Reading Comprehension Achievement in a State Islamic University. Journal of Islamic Education, 23(1), 54-64.

Silvia, O. W., \& Djuanda, D. (2017). MODEL LITERATURE BASED DALAM PROGRAM GERAKAN LITERASI SEKOLAH. Mimbar Sekolah Dasar, 4(2), 160-171. https://doi.org/10.23819/mimbar-sd.v4i2.7799

Springer, S. E., Harris, S., \& Dole, J. A. (2017). From Surviving to Thriving: Four Research- - Based Principles to Build Students ' Reading Interest. The Reading Teacher, 71(1), 43-50. https://doi.org/10.1002/trtr.1581

Steve, G., Xinghua, L., Angelique, A., Clarence, N., Brendan, B., R, H. K., \& Jennifer, H. (2016). Effectiveness of Literacy Programs Balancing Reading and Writing Instruction: A Meta-Analysis. International Literacy Association, O(0), 1-26. https://doi.org/10.1002/rrq.194

Sunardin. (2019). Perbandingan Kemampuan Membaca Pemahaman Siswa Berdasarkan Tingkat Minat Baca antara yang Belajar dengan Metode SQ3R dan Metode Quantum Reading. Cokroaminoto Journal of Primary Education, 2(1), 16-25.

Sutarti, T. (2017). Efforts to Increase Students Reading Interest on Educational Reference Through Classical Guidance and Counseling Experiential Learning Model. Journal Of Education, Teaching and Learning, 2(1), 59-64. https://doi.org/10.26737/jetl.v2i1.152

Sutrisna, I., Sriwulan, S., \& Nugraha, V. (2019). Pengaruh Gerakan Literasi dalam Meningkatkan Minat Baca Siswa. Jurnal Pendidikan Bahasa Dan Sastra Indonesia, 2(4), 521-528. 
Teguh, M. (2017). Gerakan literasi sekolah dasar. Aktualisasi Kurikulum 2013 Di Sekolah Dasar Melalui Gerakan Literasi Sekolah Untuk Menyiapkan Generasi Unggul Dan Berbudi Pekerti, 18-26.

Tichenor, M., Piechura, K., Diedrichs, R., \& Heins, E. (2020). Building a Culture of Independent Reading through Literacy Clubs. Reading Improvement, 57(1), 11-15.

Triyanto, H., \& Krismayani, I. (2019). Implementasi Gerakan Literasi Sekolah (GLS) Tahap Pembiasaan sebagai Upaya Menumbuhkan Budaya Literasi di SMP Negeri Kabupaten Kudus (Studi Kasus di SMP 1 Kudus, SMP 2 Kudus, dan SMP 1 Jati Kudus). Jurnal Ilmu Perpustakaan, 8(1), 196-206.

Walipah, E., Sopandi, W., \& Sujana, A. (2020). School Literacy Movement in the Industrial Revolution Era 4 . 0 in Building Speed Reading Skills. International Conference on Elementary Education, 2, 17631770.

Wandasari, Y. (2017). Implementasi Gerakan Literasi Sekolah (Gls) Sebagai Pembentuk Pendidikan Berkarakter. JMKSP (Jurnal Manajemen, Kepemimpinan, Dan Supervisi Pendidikan), 2(2), 325-343.

Wandasari, Y., Kristiawan, M., \& Arafat, Y. (2019). Policy Evaluation Of School 's Literacy Movement On Improving Discipline Of State High School Students. International Journal of Scientific and Technology Research, 8(4), 190-198.

Wibowo, W. (2019). Pengelolaan Gerakan Literasi Sekolah Untuk Mendukung Karya Tulis Siswa Sekolah Dasar. Media Manajemen Pendidikan, 2(2), 279-288.

Wiedarti, P., Kisyani, L., Pratiwi, R., Muldian, W., Sufyandi, S., Roosaria, D. R., Faizah, D. U., Rahayu, E. S., Yusuf, A., \& Antoro, B. (2018). Desain Induk Gerakan literasi sekolah. Kementrian Pendidikan dan Kebudayaan.

Yulianto, A., \& Maman, S. (2019). The Implementation of Reading-Writing Literacy In Secondary School. International Conference on Current Issues in Education, 326, 46-51.

Zhao, W., Song, Y., Zhao, Q., \& Zhang, R. (2018). The Effect of Teacher Support on Primary School Students ' Reading Engagement: The Mediating Role of Reading Interest and Chinese Academic Self- concept. Educational Psychology, O(0), 1-18. https://doi.org/10.1080/01443410.2018.1497146 